\title{
Overview of Economic Development of Africa
}

\section{Stephen Awuah Baffour*}

Chief Executive Officer, Kwame Nkrumah University of Science and Technology, Pan Africanism, Ghana

*Corresponding Author: Stephen Awuah Baffour, Chief Executive Officer, Kwame Nkrumah University of Science and Technology, Pan Africanism, Ghana.
Received: March 22, 2021

Published: March 29, 2021

(C) All rights are reserved by Stephen Awuah

Baffour.

Keywords: Psychology; Economic; Innovation; Productivity; Time; Procrastination; Leadership; Mindset

Everyone makes or has ambitions, But only few will succeed, the rest get caught in the gab of intentions and action. Africa is a great continent with lots of prospect. Africa is one of the richest continent in terms of agriculture, minerals and culture but remains the poorest continent. Most Africans don't accept that real battle grounds is in the mind.

The major problems that hinders the economic development of Africa is not lack of money, skilled labor, lack of innovations or what of you but rather procrastination and love of money are the top notch problematic characters among the citizens of Africa that has great negative effect on the continent of Africa. Procrastination is the illusions of quick-win , and African are mostly the victim of it. One thing I realize with most Africans is they compromise longterm success for short pleasure. They lack the idea that procrastination is simply a well afflicted wound.

Africa economy keeps deteriorating because of poor leadership, political instability and lack of practical education. Most current leaders in Africa are slaves of money and that makes them lead on with greediness and selfishness. 'money is not everything but everything needs money', this is a conspiracy truth that most Africans ignore.
Again most Africans acts as parrots rather than an eagles. Thought without action is a barrier to achieving relevant, meaningful task and instead lead them to waste precious time on trivial and invaluable activities. In my opinion, which I strongly believe is the root cause of Africans weak economy is to have a change in the mindset among it citizens before they think of economic development and success.

\section{Assets from publication with us}

- Prompt Acknowledgement after receiving the article

- Thorough Double blinded peer review

- Rapid Publication

- Issue of Publication Certificate

- High visibility of your Published work

Website: www.actascientific.com/

Submit Article: www.actascientific.com/submission.php

Email us: editor@actascientific.com

Contact us: +919182824667 